\title{
Using non-Personal Computers for eLearning: Sri Lankan Experience
}

\author{
Tharindu R. Liyanagunawardena ${ }^{1}$, Andrew A. Adams ${ }^{2}$, Naz Rassool $^{3} \&$ Shirley A. Williams ${ }^{1}$ \\ ${ }^{1}$ School of Systems Engineering, University of Reading, Reading, UK \\ ${ }^{2}$ Centre for Business Information Ethics, Meiji University, Tokyo, Japan \\ ${ }^{3}$ Institute of Education, University of Reading, Reading, UK \\ Correspondence: Tharindu R. Liyanagunawardena, School of Systems Engineering, University of Reading, \\ Whiteknights, Reading, RG6 6AY, UK. Tel: 44-118-378-6423. E-mail: t.r.liyanagunawardena@ reading.ac.uk
}

Received: March 12, 2013 Accepted: April 1, 2013 Online Published: June 20, 2013

doi:10.11114/jets.v1i2.96 URL: http://dx.doi.org/10.11114/jets.v1i2.96

\begin{abstract}
Communal Internet access facilities or telecentres are considered a good way to provide connectivity to people who do not possess home connectivity. Attempts are underway to utilize telecentres as eLearning centres providing access to learning materials to students who would otherwise not be able to take up eLearning. This paper reports on the findings of qualitative interviews conducted with 18 undergraduate students from two Sri Lankan universities on their eLearning experiences using communal Internet access centres. The findings suggest that despite the efforts by telecentres to provide a good service to eLearners, there are various problems faced by students including: costs, logistics, scarcity of resources, connectivity speeds, excessive procedures, and lack of support. The experiences of these Sri Lankan students suggest that there is much that needs to be understood about user perspectives in using telecentres, which could help formulate better policies and strategies to support eLearners who depend on communal access facilities.
\end{abstract}

Keywords: eLearning, online learning, telecentres, digital divide

\section{Introduction}

Increasing opportunities for higher education has become a challenge for many developing countries as their investments in the basic and secondary education systems start delivering and more and more learners qualify for higher education. Furthermore, it is widely argued that the global knowledge economy favours knowledge workers (Castells, 2000) for whom a degree has become a prerequisite. As global transformations have eliminated (through automation), outsourced or depressed wages below subsistence level for much unskilled and skilled but repetitive work (Klein, 2002), many people develop aspirations of gaining a higher education as a gateway for a better life.

Many countries have turned to distance education in order to increase (as well as to widen) access to higher education believing that if managed properly it can be a cost effective alternative (Bates, 2005) to the undoubtedly expensive expansion of campus facilities. In Sri Lanka where the traditional state university system can only cater for around 22,000 (around 3\% of school leaving age cohort) new entrants per year, technology mediated distance education is seen as a good option to increase university educational opportunities and to improve the quality of existing distance offerings. However, previous attempted implementations of such systems (such as the African Virtual University Project and the UK eUniversity Project) suggest that not all technology mediated educational delivery is successful.

\section{Background}

It is vital to take the context into consideration when technology mediated distance education is introduced. Bates (2005) proposes the ACTIONS frame work for technology selection and application in open and distance learning, which assesses a technology according to its Access, Cost, Teaching and learning, Interaction, Novelty and Speed of introducing new courses for a given context. Here 'access' is identified as the most important criterion for technology selection, because in open and distance learning widening and increasing participation is a priority. Through the Internet, it is possible to make learning materials available 'any time - anywhere'. However, if the equipment and connectivity needed to access the material is not available (or is shared amongst too many demands), learners may not benefit from this potential flexibility. This is especially pertinent in countries such as 
Sri Lanka, where the majority of households with computers share the resource. On the other hand, the urban elite who have access to personal laptops and Internet connections are likely to be better served by online distance education technologies. The fact that only $11.4 \%$ of Sri Lankan households have access to computers (Department of Census and Statistics Sri Lanka, 2009) severely restricts access for potential learners if digital technologies are used.

The percentage of Internet users/personal computer users in a population provides a general idea of the level of physical accessibility for people in a particular country. As a general rule a technology should be considered only if at least 70\% of the target group have access to it (Bates 2005). The United Nations Statistics Division (2010) revealed that there was a stark contrast between developed countries and developing countries with regard to the number of Internet users. For example, in the UK the number of Internet users grew from 1.9\% in 1995 to $76.24 \%$ in 2008; by that year many African countries including Niger, Ethiopia and Burundi were still only able to offer Internet access to less than $1 \%$ of the population. Furthermore the technology infrastructure of a country should also be considered in making technology decisions for delivering education because, for example, if the majority are only able to access the Internet through narrowband connectivity, there will be little benefit from the production of high quality video material and graphics-heavy interactive material as educational content.

'Access' in Bates' framework only considered physical access to educational technologies; but access to technology, as it is now understood, is not only a matter of physical access (van Dijk, 2005; Warschauer, 2003). According to Warschauer (2003):

"meaningful access to ICT comprises far more than merely providing computer and internet connections. Access to ICT is embedded in a complex array of factors encompassing physical, digital, human and social resources and relationships. Content and language, literacy and education, and community and institutional structures must all be taken into account if meaningful access to new technologies to be provided" (Warschauer 2003, p6).

This shows that not only physical access, but also language, literacy, and community and institutional support are important considerations in introducing technology to deliver education.

\subsection{Communal Access Centres (telecentres)}

Providing access through telecentres to communities who lack access to computers and the Internet is considered a good way of providing physical access (Warschauer 2003). Both developed and developing countries have established telecentres as a means of providing access, especially to rural communities. Examples are the Teleaccess project (www.teleaccess.org) in Greece, Italy, Germany, Poland, Bulgaria and Croatia and the 'Nanasala' project (www.nanasala.lk) in Sri Lanka. In Malaysia, India and Sri Lanka the use of telecentres for eLearning has been promoted (Gaiani, Hansson, Meegammana, \& Mozelius, 2009; Gamage \& Halpin, 2007).

Libraries and educational institutes' computer laboratories are other ways of providing access to computers and the Internet, especially to students. However, in order to allow fair access to all, these facilities often have time limits on usage at least during busy periods.

On the other hand, Internet cafes provide computer and the Internet access to anyone who is willing to pay their charges. But the environment at an Internet cafe may not be ideal for everyone or for learning. A recent research study on distance educational technology in South Asia showed that that there was a gender difference in using Internet cafes, with more males using them (Jamtsho, et al., 2010). Furthermore, Internet cafe charges can be unreasonably high in some instances (Liyanagunawardena, 2012). Not all learners are able to bear high costs to use Internet cafes, thus communal facilities may provide a valuable service for students who do not have their own computers and/or connectivity in accessing eLearning.

However, using communal facilities for eLearning can be a challenge for learners due to a range of problems such as: physical access to centres, digital literacy and language (Gamage \& Halpin, 2007; Liyanagunawardena, Adams, Rassool, \& Williams, 2013) while sustainability of telecentres is also a concern in many instances (Liyanagunawardena, 2012).

\subsection{Online Distance Education in Sri Lanka}

Sri Lanka is experiencing a chronic shortage of places for higher education in the state university system. In the late 1990s the option of providing online distance education as an alternative was considered due to a perception of quality improvement and cost reduction (Loxley, Ho, Vandenabeele, Gutierrez, \& Chanmugam, 2003). The Distance Education Modernization Project (DEMP), funded through a loan from the Asian Development Bank (2003-2010), was the main effort to introduce online distance education to Sri Lanka. This project was expected to facilitate online learning for 165,000 distance learning students registered with the state universities and around 
40,000 students registered with other public and private institutions (Loxley, et al., 2003). This capacity was expected to double over the first five years. The DEMP consisted of several sub-projects of which one was responsible for improving distance education programmes' content, quality and distribution. To provide access to students who do not have Internet connectivity, a 'National Distance Education Network' was set up, linking the Open University of Sri Lanka and other private and public post-secondary institutions. Partner institutes are able to use it to host their online distance education programmes while students are able to access the programmes through telecentre facilities established under it. This telecentre service is called the National Online Distance Education Service (NODES) and there were 26 centres established under this project, which are called NACs (NODES Access Centres). Each telecentre or NAC consists of the same amount of resources: computers, printers, scanners, etc. Students registered with partner institutes are able to access the telecentres 'free of charge'.

\section{Method}

The research project investigated the impact of ICTs on Distance Education in Sri Lanka using an ethnographic research approach. Multiple case studies were investigated to understand the current situation in Sri Lanka. Questionnaires, qualitative interviews and documents were used to collect data from 3 levels of participants: policy making authorities, policy implementing authorities and end users of implemented system - students, tutors and lecturers. In this paper, the authors are presenting their findings on student experiences of accessing online higher education through communal facilities based on qualitative interviews and a group interview with 18 students registered on distance education programmes of two universities. The data presented here addresses the research question "what is your experience of using communal facilities for eLearning?"

\subsection{Sample}

The research study was advertised through official channels at two universities: Yellow Fields University (YFU) and Orange Valley University (OVU) (pseudonymous). Ten students registered on distance education programmes with an online presence at the YFU (these students came from three different degree programmes) and eight students registered on the online distance education programme of the OVU participated in the research.

\subsection{Participant Characteristics}

The sample included four females (22\%): two from each university. The population demographics showed that $39 \%$ of OVU students and $26 \%$ of ICT students at the YFU were female (population demographic data could not be gathered for other two programmes), thus the percentage of females who participated in the interviews could be justified. The sample age ranged from 23-41 years at OVU and 23-29 years at YFU.

\subsection{Sampling Procedures}

Students were invited to participate in the research through course co-ordinators/lecturers and the participation was voluntary. A raffle draw, which offered a cash prize of Rs.2,500 (about £14) was advertised in the information sheet presented. The winner was drawn from the names of interview participants who wished to enter the draw. This incentive was offered to show the recipients that their time and participation was valued. At the same time, a raffle draw was decided to avoid anyone participating in the research solely to claim the incentive.

\subsection{Methods}

Both one-on-one qualitative interviews (face-to-face, via telephone, or via Skype ${ }^{\mathrm{TM}}$ ) and group interviews were conducted to interview the participants. The use of telephone and Skype ${ }^{\mathrm{TM}}$ for interviewing was especially useful in this case as the students were distance learners based in a broad geographic area. Interviews were conducted either in English or Sinhala language as preferred by the interviewee. In one instance where the interviewee was a Muslim female whose first language is Tamil, English had to be used as the common language medium. The group interview was conducted in Sinhala with four students of the YFU. All interviews were audio-recorded and later transcribed; the interviews conducted in Sinhala were translated to English and were verified. Some participants were contacted after the interviews for respondent verification where clarifications were required.

\section{Results and Discussion}

All eight interview participants from the OVU and seven out of the ten interview participants (70\%) from the YFU possessed home computers. All interview participants except one (who used mobile phone to access the Internet) from the OVU had broadband Internet connections. However, not many had home Internet connectivity when they had started the study programme; so they had used communal Internet access options initially and later acquired home connectivity. On the other hand, only five interview participants (50\%) at YFU had home Internet connectivity. As there were computer laboratories and a telecentre in the YFU main campus premises, students who did not have home connectivity gained access via these. 


\subsection{Cost of Connectivity}

Students who possessed ready access to the Internet appreciated the flexibility of online learning while for others it was yet another burden because they had to go to a telecentre, a library, an Internet cafe, or to a friends' place to go online. Students who were not economically secure were anxious of introducing online learning as they could not afford to pay extra for Internet access. They also feared possible increases in course fees. Even though students at OVU believed that they received 'free access' to the Internet from telecentres set up under the DEMP, in reality the university was paying a large sum of money for this service, which was passed on to the students in their fees. YFU had negotiated a lower fee to its students but students felt even that was too much of a burden on them. For example, Manu, a 23 year old male from YFU said:

"I have to be honest here. There is a big problem with regard to these NACs [telecentres].They charge around Rs.900 [about £5] from us for NACs and that payment is a burden for some students. Some may think it is just Rs.900 but that is in fact a burden for some students. The other thing is that we're allowed to use those resources only for a limited time period."

Because the fee to access telecentres set up under the DEMP was coupled to tuition fee, students who already had Internet access at home and never used these telecentres still had to pay for it, causing them to be paying twice for access.

Some students who used Internet cafes had to pay an exorbitant fee for an hour of Internet access as these charges are not regulated. For example, Liyanagunawardena's (2012) analysis shows that an Internet cafe situated outside Colombo can charge 15 times more for an hour of Internet access than a cafe situated in Colombo.

\subsection{Logistics}

Even though it was hoped that telecentres would provide ready access to online learning materials, students had to endure great difficulties to use them. Because there were only 26 telecentres established under the DEMP (that provided "free access" to registered students), some students had to travel a long distance to reach one of the centres. For example, Bandula from a remote village in Hambantota had to travel at least $60 \mathrm{~km}$ to reach the nearest telecentre while another from Kandy endured two bus rides, which took at least 45 minutes (one-way), to access the Internet from her educational institute. Many students complained of traffic blocks and the lack of a reliable public transport service. As a result, students visiting these communal access centres spent a considerable amount of time in transit. For example, Nirodha, a 24 year old male, described his experience:

"Initially I too used the NODES access centre [telecentre] at Nawala. [...] It takes time to get there. Even after going there, we can spend only a limited time [within the opening hours]. No matter how early we start [the journey], due to bus traffic involved we only get little time to spend at the centre. Later on considering the bus fares and time spent I felt it would be more economical to continue studies by acquiring an ADSL [Asymmetric Digital Subscriber Line] connection".

Nirodha was lucky to be able to acquire an ADSL connection, which was preferred over mobile broadband connectivity by all participants due to perceived quality of connection and lower cost. However, Sri Lanka Telecom's ADSL service is only available to a minority of the population (living close to city centres). Therefore the only option for broadband connectivity for the majority is the more expensive mobile broadband service.

\subsection{Opening Hours}

Telecentres established under the DEMP were said to be operative throughout the week according to demand (Liyanage, 2010). However, this did not suit the needs of employed students who claimed that these were closed at the weekend when they had free time. Given sufficient notification telecentre staff did try to accommodate some student requests and to open their centres at the weekend but only one student had ever visited a centre at the weekend. Students who used Internet cafes also had similar complaints.

\subsection{Staff Knowledge and Awareness}

Telecentre staffs are expected to support students who face technical difficulties. However, students felt that the telecentre staff lacked knowledge and awareness to be of help. In one instance when a student wanted to take duplex printouts the staff was not able to assist him.

"We don't know how to do duplex printing on that machine. The staff there tells us that the machine does not support duplex printing [...] When I got employed and went into the working environment I got to know that those machines actually have the facility for duplex printing. Even the staff there doesn't know that." 


\subsection{Limitations on Software Use}

Telecentre computers are equipped with a set of software that has been selected to offer a good service to its users. When students who were using telecentre facilities wanted to use software other than those that were installed, there was no such option. Thus, students who could afford to acquire Internet connections left the telecentre facilities. For example, Nirodha, registered on an online degree programme commented:

'We were not allowed to use software such as 'TeamViewer' at the NODES access centre [telecentre]. We were unable to install software we required due to limitations at the centres. It is not only the Internet facility that we use, we also use screen sharing software such as 'TeamViewer'. But we can't use those there."

This was especially a problem for students who were registered in an IT programme because they had to use different software to complete their assignments.

\subsection{Limited Access Time}

Of the 26 telecentres established, all with identical physical resources, usage varied substantially. For some they were hardly used but for others demand was so high that time limits were introduced to ensure fair distribution of the resources amongst users of that particular centre. According to Chandrasiri, 32 year-old male, who was using a telecentre in Colombo, students were allocated one time slot per week. However, in his experience, when there were no users at the centre, even if a student had already used up their quota, use of the facilities was permitted. Liyanagunawardena (2012) found that the Anuradhapura telecentre was used by only one individual from August to October 2009 while Monaragala, Kurunagala, Kegalle, Galle, Anuradhapura, Ambalantota, and Ambalangoda centres had fewer than 25 individuals visiting them each month during the period of August to November 2009. Because all these centres had the same number of computers, scanners, photocopiers and printers, while some resources were idling in remote locations, users in some centres had restrictions in terms of access times, to ensure fair access for all.

\subsection{Excessive Procedures}

Some telecentres were said to practice stringent procedures such as demanding students to bring written approval from the vice chancellor of their university in order to issue a set of headphones in order to listen to a video lecture. Clearly, it is impractical to expect each student wanting to listen to a video lecture to present a letter from the vice chancellor of his/her university. In fact students of the YFU who participated in the study were so fed-up of these excessive procedures of the telecentre situated in the same premises as their university main campus that they refrained from using it.

\subsection{Resource Access Limitations}

One could argue that the telecentres actively discouraged access to hardware resources by demanding letters from the Vice Chancellor of a university for the simple matter of issuing a set of headphones. Moreover, some web resources such as social networking sites (eg. Facebook) and video sharing sites (eg. YouTube ${ }^{\mathrm{TM}}$ ) were among the resources that were blocked from telecentres. Students were using these resources to share information for group projects as well as to research on subjects they were studying. Pulathisi felt that in order to make learning at a distance more effective with the use of ICTs, it was necessary to allow access to all resources without blocking them.

"Why is it that only NAC [telecentre] has problems with Facebook? They block sites saying students chat in those sites. [...] What I am saying is, if one is doing distance learning one has to chat. Because if online components are there one has to chat. If we have to discuss something with a lecturer one can use that. Sometimes a student may exchange things over Facebook or email. So accessing those resources should be allowed."

The YFU has identified the importance of chat as a tool for supporting distance education and introduced a "virtual office hour", allowing students to chat with their lecturer. Furthermore, their decision to block the video sharing site YouTube ${ }^{\mathrm{TM}}$ had adverse impact on engineering students who used the site to view videos that helped them understand product designing. For example, Pulathisi described the problem they are experiencing as engineering students.

"We as engineering students need to view video lectures, read notes. We also have to go to other networks. When we try to go to some of the links they have been blocked. I don't know what the reason is."

Dinesh, 23 year-old male, added that they could not do research into product designs due to the restrictions imposed and questioned the reason for such blockages.

“We have a subject called 'Product Design'. For that we need to observe how others have done similar 
designs. So what do we do but study similar kinds of product designs through YouTube. But we don't have that opportunity now because it is blocked. Why do they implement such limitations?"

Telecentres were said to discourage the use of pen drives or USB drives; some educational institutes in Sri Lanka too used to discourage the use of pen drives in an attempt to reduce virus threats. However, in order to save their work to be accessed elsewhere, especially from a computer that does not have an email facility, students have no other option but to use a pen drive (or other removable media). As such discouraging the use of pen drives reduces the usefulness of telecentres, particularly for those with their own computers but no Internet access.

In contrast, communal computer laboratories of the YFU allowed the use of removable media. They also did not block online chat facilities, but students admitted that they did not use online-chat on the university computer laboratories. University computer laboratories also blocked web sites such as Facebook and YouTube ${ }^{\mathrm{TM}}$ claiming that it was due to limited bandwidth.

\subsection{Computer Literacy and Language Issues}

All participants were competent computer users and had good English language skills. However, many participants' had friends who experienced problems with English language skills and computer skills. There is very little useful content found in local languages (Sinhala and Tamil) on the Internet. This together with low computer literacy levels in the country (20.3\% in 2009 where computer literacy was considered the ability to use a computer on one's own even just to play a game) suggests that there will be a large majority of people who will not be able to study on programmes using eLearning unless there is a conscious effort to increase computer literacy and international language skills in the country.

\subsection{Connection Quality}

Most students complained that the Internet connection was too slow. This is in consistent with the findings of Baggaley and Batpuev (2007) who found browser loading times to be nearly four times slower than the 10 seconds bench mark (Nielsen, 1993). One participant and two of her friends faced difficulties while attempting an online quiz at YFU's computer laboratory. These students had to repeat the exam as their quizzes did not get submitted. The lack of reliability in connection has made online quizzes a stressful experience for students as there is no guarantee that the quiz could be submitted at the first attempt.

Students who tried to download multimedia files from Internet cafes failed to download them due to slow connections. Work by the PANdora research network has revealed that Internet cafe use is not popular in Asian countries due to slow connectivity and virus issues. Many have complained also of the inability to download multimedia files (Wikramanayake \& Baggaley, 2010), which is in consistent with student claims.

Due to all these issues faced in accessing the Internet and other resources from communal access facilities a respondent remarked:

"Well if you don't have an Internet connection at home it is very difficult. In my opinion it is compulsory that one has a home Internet connection [in order to take up a course that uses eLearning]"

This shows that even though authorities expected telecentres to serve as eLearning centres and to open educational opportunities through online programmes for students who did not have places on in-person programmes, this was far from what was taking place in practice. Students felt that a home connection is essential in order to continue an eLearning programme due to the difficulties they had to face in communal access facilities.

\section{Conclusion}

Sri Lanka has yet to improve its infrastructure and per capita income for a sizable number of the population to be able to afford home computers. Current low computer ownership suggests that home Internet connectivity is likely to be even lower showing the importance of public access centres such as telecentres and libraries. The government has identified the importance of providing public access centres; through the Distance Education Modernization Project have implemented telecentres especially for the purpose of distance learning through eLearning.

However, the facilities provided through these telecentres have not gained popularity among distance learning students despite offering access "free of charge". Logistics, opening hours, lack of staff support, limited access time, connection quality, resource access limitations and excessive procedures were some of the difficulties faced by students in using these facilities.

Better planning, for example considering the potential demand for each telecentre before allocating resources (without allocating the same amount of resources for all), could help better utilization of resources. Monitoring through a periodic customer satisfaction survey could help identify issues such as inflexible opening hours, 
excessive procedures and lack of staff assistance. Identifying reasons for customer dissatisfaction can help address those issues to make telecentres more student-friendly and welcoming. In developing countries such as Sri Lanka where universal access to computers and Internet is far from reach, improving communal access facilities is important to provide access to eLearning as well as to build digital literacy.

\section{Acknowledgements}

The first author would like to thank the University of Reading for the PhD studentship she received.

\section{References}

Baggaley, J., \& Batpurev, B. (2007). The World-Wide Inaccessible Web, Part 1: Browsing. International Review of Research in Open and Distance Learning, 6(2). Retrieved from http://www.irrodl.org/index.php/irrodl/article/view/438/917

Bates, A. W. (2005). Technology, E-Learning and Distance Education (2nd ed.). Oxon: Routledge. http://dx.doi.org/10.4324/9780203463772

Castells, M. (2000). End of Millennium (2nd ed.). Oxford: Blackwell. http://dx.doi.org/10.1002/9781444323436

Department of Census and Statistics Sri Lanka (2009). Computer Literacy Survey - 2009 Retrieved March 27, 2012, from http://www.statistics.gov.lk/CLS/BuletinComputerLiteracy_2009.pdf

Gaiani, S., Hansson, H., Meegammana, N., \& Mozelius, P. (2009). Critical Issues for E-Learning Telecentres in Sri Lanka and India. Paper presented at the M-2009. 23rd ICDE World Conference on Open Learning and Distance Education.

Gamage, P., \& Halpin, E. F. (2007). E-Sri Lanka: bridging the digital divide. The Electronic Library, 25(6), 693-710. http://dx.doi.org/10.1108/02640470710837128

Jamtsho, S., Rinchen, S., Sangi, N. A., Ahmed, S., Wikramanayake, G. N., Wimalaratne, P., et al. (2010). Accessibility, Acceptance and Effects of Distance Education in South Asia. In J. Baggaley \& T. Belawati (Eds.), Distance Education Technology in Asia, 33-56, New Delhi, India and Ottawa, Canada: Sage Publications India and International Development Research Centre.

Klein, N. (2002). No Logo. New York: Picador.

Liyanage, L. (2010). Technology Enabled Delivery of Distance Education: Challenges and Opportunities in Sri Lanka. Paper presented at the World Conference on e-Lerning in Corporate, Government, Healthcare, and Higher Education Orlando, Florida.

Liyanagunawardena, T. R. (2012). Information Communication Technologies and Distance Education in Sri Lanka: A case study of two universities. PhD Thesis, University of Reading, Reading.

Liyanagunawardena, T. R., Adams, A. A., Rassool, N., \& Williams, S. (2013). Telecentres and eLearning, British Journal of Educational Technology (in press).

Loxley, W., Ho, S., Vandenabeele, C., Gutierrez, L., \& Chanmugam, S. (2003). Report and Recommendation of the President to the Board of Directors on Proposed Loan to the Democratic Socialist Republic of Sri Lanka for the Distance Education Modernization Project.

Nielsen, J. (1993). Response Times: The 3 Important Limits. San Francisco: Morgan Kaufmann. Retrieved March 27, 2012, from http://www.useit.com/papers/responsetime.html.

United Nations Statistics Division (2010, June 23, 2010). Millennium Development Goals Indicators: Internet Users per 100 Population Retrieved April 05, 2012, from http://millenniumindicators.un.org/unsd/mdg/SeriesDetail.aspx?srid=605\&crid=

van Dijk, J. (2005). The Deepening Divide: Inequalities in the Information Society, Thousand Oaks: Sage.

Warschauer, M. (2003). Technology and Social Inclusion: Rethinking the Digital Divide, Cambridge: MIT Press.

Wikramanayake, G., \& Baggaley, J. (2010). Accessibility and Selection of Distance Education Media. In T. Belawati \& J. Baggaley (Eds.), Policy and Practice in Asian Distance Education, 149-155, New Delhi, India and Ottawa, Canada: SAGE Publications India and International Development Research Centre.

\section{(cc) $\mathrm{Br}$}

This work is licensed under a Creative Commons Attribution 3.0 License. 